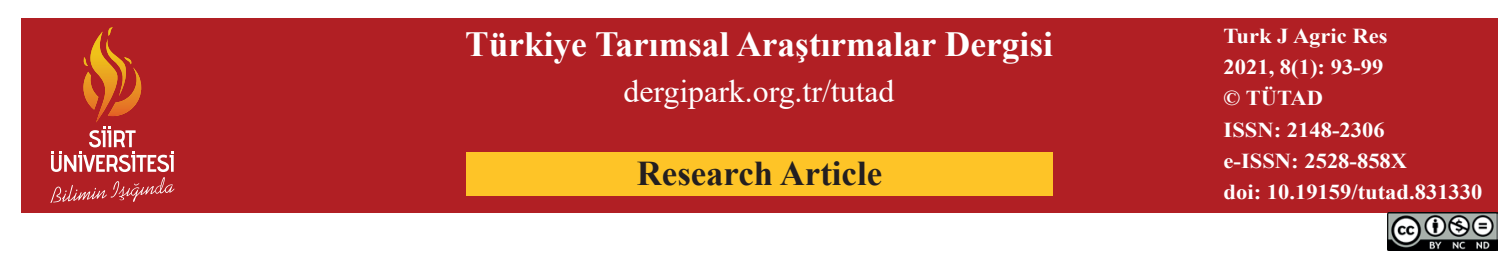

\title{
Effect of Skipping Irrigation in Different Phenological Periods on Yield and Some Physiological Parameters of Corn (Zea mays L.)
}

\author{
Timuçin TAŞ" \\ GAP Agricultural Research Institute, Department of Field Crops, Şanluurfa, TURKEY
}

\begin{tabular}{l}
$\qquad$ Received: $25.11 .2020 \quad$ Accepted: 16.02 .2021 \\
\hline ORCID ID \\
(D) orcid.org/0000-0002-2144-9064 \\
"Corresponding Author: ttas_4@hotmail.com
\end{tabular}

\begin{abstract}
This study was carried out in Southeastern Anatolia Region in Turkey between 2017 and 2018 to determine the effect of irrigation skipping in different phenological periods on yield and some physiological properties of corn (Zea mays L.) in second crop conditions. The trial is designed as randomized complete block design with three replications. DKC-6664 hybrid corn variety having classified as moderate maturity in the FAO (650-700) maturity classes were used in the study. Four irrigation skipping periods which are full irrigation treatments (S1, control), irrigation skipping in vegetative growth period (S2), irrigation skipping in pollination period (S3), and irrigation skipping in generative development period (S4) were studied in the research. According to the two-year averages; there were statistically significant differences in hybrid corn variety in terms of investigated characteristics. According to results, grain yield (GY), chlorophyll content (CC, spad), water use efficiency (WUE, $\mathrm{mm}$ ), crop water stress index (CWSI) and plant water consumption (ETa, mm) were ranged from 12761.5 (S2)-14021.3 (S1) kg ha-1, 39.10 (S4)-44.50 (S1) spad, 1.902 (S1)-2.114 (S3) mm, 0.18 (S3)-0.33 (S4) and 6752 (S3)-7712.0 (S1) mm respectively. Because of drier weather conditions in 2017 compared to 2018, while GY, CC, and WUE parameters decreased, CWSI and ETa parameters increased. In the first year of the trial when dry weather conditions prevailed, the corn variety consumed more water and was more stressed. As a result, yield losses were experienced. There were positive and significant correlations between GY and CC and WUE, and negative and significant correlations between CWSI. The results of the study indicated that irrigation should not be skipped during the entire vegetative period for economical and profitable corn production in semi-arid regions.
\end{abstract}

Keywords: Corn, phenological period, irrigation skipping, yield, physiological parameter

\section{Introduction}

Corn (Zea mays L.) is a multipurpose crop with wide adaptability to different agro-climatic conditions. It is grown in most parts of the world, up to $3000 \mathrm{~m}$ above sea level (Pandit, 2016). This crop is preferred by farmers due to its grain production potential being the highest among cereals (Chakraborty et al., 2012). Corn is ranked second after wheat in terms of cultivation area (192.05 million ha) but takes first place in terms of production (1.108.62 million ton) and grain yield per unit area $\left(5.77 \mathrm{t} \mathrm{ha}^{-1}\right)$ in the world (Anonymous, 2019). Corn is also ranked third after wheat and barley with 592000 hectares and 5.7 million tons in terms of cultivation area and production in Turkey. Furthermore, grain yield per unit area in Turkey is above the average of the world. In recent years, corn cultivation area and production quantity and its importance have been soared in both Southeastern Anatolia Region and Turkey. Almost 10\% of Turkey's grain corn production is obtained from Şanlıurfa province in the Southeastern Anatolia Region (Anonymous, 2018a).

Most varieties of corn in the world grow under rainy conditions and it is one of the most sensitive crops to drought except rice (Xiao et al., 2005). Water stress is caused by a decrease in the content of soil available water due to the constant water loss by transpiration-evaporation (Jaleel et al., 2009). The effect of water stress on the plant depends on several factors, including the severity of water stress, the time it occurs and its length, and the stages of plant growth (Jasim et al., 2020). Hence, 
loss of grain production in the dry season is connected to shortages of water used for irrigation (Pandit, 2017). The loss of yield varies from 30$90 \%$ depending on the crop stage and the degree and duration of water deficit stress (WDS) (Pandit, 2018). The stages of corn susceptible to WDS are the vegetative, silking (flowering) and ear stages (grain filling), where yield loss may be as high as $25 \%, 50 \%$, and $21 \%$, respectively (Denmead and Shaw, 1960). In a study conducted under Indian conditions, it was reported that corn yield decreased by about $45 \%$ in water deficit applied in the vegetative period of corn (Sah et al., 2020). The crop water stress index (CWSI) is used to measure the stress levels of plants under drought and hightemperature conditions. The CWSI was developed through the relationships between vapor pressure deficit and the difference between the canopy and environmental air temperature (Yazar, 2009). Insufficient available soil water weakens the metabolic activity of corn, reduces biomass accumulation, and decreases its photosynthetic rate by reducing the chlorophyll content (CC) in leaves, eventually leading to a decrease in corn yield ( $\mathrm{Bu}$ et al., 2010). A strong water stress during the vegetative growth stage could seriously inhibit the growth and leaf area of corn plants and decrease the yield (Cakir, 2004). However, corn under light water stress during early vegetative growth and late grain-filling stages showed a certain level of water stress tolerance due to the low water demand of corn during these stages (Tariq and Usman, 2009). Therefore, a high corn yield could be achieved through full irrigation at the flowering stage, even if the soil water content is sub-optimal during the vegetative growth and grain-filling stages (Igbadun et al., 2007). Many studies have explored the effects of water stress on the growth and development of corn (Tariq and Usman, 2009).
Steele et al. (2000) indicated that deficit irrigation can be applied when the water supply is insufficient, thus some yield reduction can be tolerated in irrigation skipping applications considering the critical plant growth periods. Rajasekar et al. (2020) reported that deficit irrigation programs can be implemented either by distributing the water deficit equally throughout the season, or irrigation can be skipped in one or several development periods. The purpose of this study was to determine the effects of irrigation skipping during different phenological periods on yield and some physiological parameters of corn under Akçakale conditions which have a semi-arid climate in Turkey.

\section{Material and Methods}

The study was carried out under Akçakale-Şanlıurfa region conditions in Turkey during the 2017 and 2018 second crop corn growing seasons (from June to November). The research area is located between $36^{\circ} 90^{\prime} 23^{\prime \prime} \mathrm{N}$ latitudes and $38^{\circ} 20^{\prime} 92^{\prime \prime}$ E longitudes and elevation from the sea level of the experimental field is about $500 \mathrm{~m}$. The trial site is dry and hot in summers and relatively mild in winters. While the average temperature reaches 40 degrees in the trial site in July and August and exceeds 30 degrees on some summer nights. The weather is the coldest in December and January on the trial site. Soil samples were taken for analysis at the depth of 0-30 and 30$60 \mathrm{~cm}$ from the area during 2017 and 2018. Except for the low organic matter ratio and available phosphorus $(\mathrm{P})$, other soil properties were within acceptable limits in terms of plant development. The physical and chemical properties of the trial soil were given in Table 1. Irrigation water was classified as $\mathrm{C} 2 \mathrm{~S} 1$, which is considered safe to be used in corn irrigation. During June, July, and

Table 1. Physical and chemical properties of soil in the trial area in 2017 and $2018^{*}$

\begin{tabular}{|c|c|c|c|c|}
\hline \multirow{3}{*}{ Soil properties } & \multicolumn{2}{|c|}{2017} & \multicolumn{2}{|c|}{2018} \\
\hline & \multicolumn{4}{|c|}{ Soil depth (cm) } \\
\hline & $0-30$ & $30-60$ & $0-30$ & $30-60$ \\
\hline Sand (\%) & 18.24 & 20.24 & 18.77 & 21.33 \\
\hline Clay (\%) & 65.76 & 67.76 & 64.65 & 66.55 \\
\hline Silt $(\%)$ & 16.00 & 12.00 & 16.58 & 12.12 \\
\hline Electrical conductivity $\left(\mathrm{dS} \mathrm{m} \mathrm{m}^{-1}\right)$ & 0.640 & 0.660 & 0.670 & 0.740 \\
\hline $\mathrm{pH}$ & 7.30 & 7.20 & 7.60 & 7.70 \\
\hline Lime $\left(\mathrm{CaCO}_{3}\right)(\%)$ & 25.0 & 27.1 & 31.2 & 32.0 \\
\hline Organic matter $(\%)$ & 0.83 & 0.81 & 1.04 & 0.79 \\
\hline Available phosphorus $\left(\mathrm{kg} \mathrm{P}_{2} \mathrm{O}_{5} \mathrm{ha}^{-1}\right)$ & 54.3 & 51.0 & 40.2 & 45.5 \\
\hline Available potassium $\left(\mathrm{kg} \mathrm{K}_{2} \mathrm{O} \mathrm{ha}^{-1}\right)$ & 2500 & 2401 & 2302 & 2231 \\
\hline
\end{tabular}

*: Soil samples were analyzed in GAP Agricultural Research Institute central laboratory in Turkey

August, the temperature was reached above $40{ }^{\circ} \mathrm{C}$ and the prominent difference in day and night temperatures was observed. Besides, relative humidity values below $50 \%$ were measured in these months. There was no rainfall during the corn growing season in both years of the study. Some 
climatic data for the duration of the study, belonging to the second crop season of corn in 2017-2018, were given in Table 2. All plots were irrigated after sowing at field capacity to ensure homogeneous germination. Seeds of DKC-6664 hybrid corn variety was used as the plant material of the experiment. The DKC-6664 is classified as moderate maturity in the FAO (650-700) maturity classes.

The experiment was laid out according to randomized complete block design, with three replications of 3 phenologic periods and full irrigation (control). The treatments were; control (S1) in which full irrigation water was applied to irrigate a soil profile of $0-90 \mathrm{~cm}$ depth to field capacity. The moisture content in S1 treatment was controlled continuously by the gravimetric method. Irrigation was performed when $50 \%$ of the soil moisture in 0-90 cm effective root depth was lost. The experiment included three irrigation skipping in different phenological periods, which were; Vegetative growth period (S2) in which corn plants have 12 to 14 leaves, pollination period $(\mathrm{S} 3)$ which is between the end of vegetative and the beginning of generative development periods, and generative development period (S4) which is between the end of milk kernel and end of dough stages. The plants were partially subjected to water stress by skipping an irrigation event during each of the indicated development periods.

The trial area was made ready for sowing in the last week of June after the wheat harvest. Nitrogen was applied at the rate of $50 \mathrm{~kg} \mathrm{~N} \mathrm{ha}^{-1}$, four weeks after sowing $(\mathrm{N})$ as ammonium nitrate $(33 \% \mathrm{~N})$, while $\mathrm{N}$ and $\mathrm{P}$ were added once with seedbed preparation at the rate of $50 \mathrm{~kg} \mathrm{ha}^{-1} \mathrm{~N}$ and $50 \mathrm{~kg} \mathrm{ha}^{-1}$ $\mathrm{P}_{2} \mathrm{O}_{5}$ as mixed fertilizer $\left(20.20 .0 \% \mathrm{~N}, \mathrm{P}_{2} \mathrm{O}_{5}\right)$. The dimension of the experimental unit was $5 \mathrm{~m} \times 2.80$ $\mathrm{m}$. Each plot was consisted of 4 rows with $5 \mathrm{~m}$ in length and $0.7 \mathrm{~m}$ of row spacing. The plant population of the trial was about 95000 plants ha(Anonymous, 2017).
Soil samples were collected from 0-30, 30-60, and $60-90 \mathrm{~cm}$ depths to determine soil moisture content. Soil moisture content determined for each layer was converted to the moisture content in depth using the Equation 1.

$$
d=\frac{\left(P w-P w_{A W}\right) x A s \times D}{100}
$$

In the equation; $d$ is the soil moisture content in depth $(\mathrm{mm}), P w$ is the moisture content at field capacity (\%), $P w_{A W}$ is the moisture content of each layer $(\%)$, as is the soil bulk density $\left(\mathrm{g} \mathrm{cm}^{-3}\right)$, and $D$ is the layer depth (mm) (Zeleke and Wade, 2012).

Evapotranspiration that occurred in the experimental field was calculated using the Equation 2.

$$
E T_{a}=P+I-R_{f}-D_{p} \mp \Delta S
$$

In the equation, ETa is the evapotranspiration $(\mathrm{mm}), \mathrm{P}$ is the precipitation $(\mathrm{mm}), \mathrm{I}$ is the amount of irrigation water $(\mathrm{mm}), \mathrm{R}_{\mathrm{f}}$ is the surface flow $(\mathrm{mm}), \mathrm{D}_{\mathrm{p}}$ is the deep infiltration $(\mathrm{mm})$, and $\Delta \mathrm{S}$ is the soil moisture variation in the root zone $(\mathrm{mm})$. The dripping rate opted for the study was lower than the infiltration rate of experimental soil, therefore surface flow did not occur in any of the plots.

The crop water stress index (CWSI) was calculated using the empirical method recommended by Idso et al. (1982) (Equation 3).

$$
C W S I=\frac{\left[\left(T_{c}-T_{a}\right)-L L\right]}{U L-L L}
$$

In the equation, the CWSI is the crop water stress index, $T c$ is the canopy temperature $\left({ }^{\circ} \mathrm{C}\right) ; T a$ is the air temperature $\left({ }^{\circ} \mathrm{C}\right), L L$ is the lower limit of water stress (limit value at plant transpires at the potential rate); and $U L$ is the upper limit of water stress (the limit value at which plant does not transpire).

$\mathrm{CC}$ was determined using a portable chlorophyll meter device (Minolta SPAD- 502, Osaka, Japan) that indirectly measures the amount of chlorophyll

\begin{tabular}{|c|c|c|c|c|c|c|c|c|c|c|c|c|}
\hline \multirow[t]{2}{*}{ Months } & \multicolumn{3}{|c|}{$\begin{array}{c}\text { Mean temperature } \\
\left({ }^{\circ} \mathrm{C}\right) \\
\end{array}$} & \multicolumn{3}{|c|}{$\begin{array}{c}\text { The highest } \\
\text { temperatures }\left({ }^{\circ} \mathrm{C}\right)\end{array}$} & \multicolumn{3}{|c|}{$\begin{array}{c}\text { The lowest } \\
\text { temperatures }\left({ }^{\circ} \mathrm{C}\right)\end{array}$} & \multicolumn{3}{|c|}{$\begin{array}{c}\text { Mean relative humidity } \\
(\%)\end{array}$} \\
\hline & 2017 & 2018 & ALY & 2017 & 2018 & ALY & 2017 & 2018 & ALY & 2017 & 2018 & ALY \\
\hline June & 29.1 & 28.3 & 28.1 & 42.7 & 42.6 & 37.6 & 16.0 & 16.6 & 15.5 & 30.7 & 41.4 & 35.0 \\
\hline July & 33.0 & 31.3 & 31.9 & 44.7 & 43.0 & 41.7 & 19.1 & 19.1 & 18.2 & 29.0 & 38.7 & 32.3 \\
\hline August & 31.1 & 31.1 & 31.3 & 45.3 & 42.6 & 41.3 & 18.3 & 19.4 & 17.9 & 40.2 & 40.9 & 31.4 \\
\hline September & 27.5 & 27.4 & 26.8 & 40.8 & 40.6 & 38.9 & 13.4 & 14.7 & 11.9 & 41.6 & 41.5 & 29.9 \\
\hline October & 19.5 & 20.7 & 20.2 & 31.1 & 34.2 & 31.1 & 1.8 & 5.6 & 3.5 & 43.0 & 54.3 & 43.1 \\
\hline November & 13.2 & 12.6 & 12.8 & 25.6 & 28.0 & 23.7 & -0.9 & 3.3 & 4.4 & 57.2 & 81.0 & 64.8 \\
\hline Average & 25.6 & 25.2 & 25.2 & 38.4 & 38.5 & 35.7 & 11.3 & 13.1 & 11.9 & 40.3 & 49.6 & 39.4 \\
\hline
\end{tabular}
in the leaf.

Table 2. Meteorological data of the trial area (Anonymous, 2018b)

Türkiye Tarımsal Araştırmalar Dergisi - Turkish Journal of Agricultural Research 
Grain yield $(G Y)\left(\mathrm{kg} \mathrm{ha}^{-1}\right)$ : Each plot was harvested to determine the cob weight for the experimental field. The corrected weight $(\mathrm{CW})$ was calculated according to the $15 \%$ moisture content to determine the plot yield (Equation 4) (Sarikurt and Bengisu, 2020).

$C W=$ Weight of plot $x[(100-\%$ Moisture $) / 85] x$ (Grain/Cob ratio)

Grain yield per hectare was calculated as follows (Equation 5).

$$
G Y=\frac{M W \times 10000}{\text { Harvest area in a plot }\left(\mathrm{m}^{2}\right)}
$$

The effect of irrigation skipping treatments on yield and some of the physiological parameters of corn was assessed using variance analysis (ANOVA). The experiment was laid out according to randomized complete block design with three replications. The Least Significant Difference (LSD) multiple comparison tests were used to separate the means of treatments when ANOVA indicated a significant difference between the treatments. A correlation test was performed to determine the relationships between yield and physiological parameters. Statistical analyses were carried out using JUMP 5.0.1 software (Der and Everitt, 2002).

\section{Results and Discussion}

The difference between years was found statistically significant $(\mathrm{p}<0.01)$ for GY, CC, water use efficiency (WUE), CWSI, and ETa. The difference between phenological periods was found statistically significant for GY, CC, and CWSI in combined years $(p<0.01)$. The difference between phenological periods was found statistically significant for WUE in combined years $(p<0.05)$. The difference between phenological periods was found statistically not significant for ETa in combined years $(\mathrm{p}<0.05)$. The average seasonal water consumption of corn was calculated as 771.2 $\mathrm{mm}$. Monthly water consumption varied between 90 and $195 \mathrm{~mm}$ (3 to $6.5 \mathrm{~mm}$ a day). The average net irrigation water was $410 \mathrm{~mm} \mathrm{~m}^{-2}$, while total irrigation water was $585.71 \mathrm{~mm}$ (Table 3 and 4).

While higher temperature and lower relative humidity in the first year compared to the second year caused an increase in CWSI and ETa, GY, CC, and WUE decreased. In the first year, unfavorable climatic conditions reduced the efficiency of light usage in photosynthesis activity in leaves and close stomata and reduced gas exchange and $\mathrm{CO}_{2}$ intake. As a result, grain yields and chlorophyll contents decreased. Drought stress was most likely related to the air temperature anomalies, which were $3.8^{\circ} \mathrm{C}$ and $3.1{ }^{\circ} \mathrm{C}$ above the average. It has been reported that the increase in these temperatures adversely affects plant growth (Song et al., 2019).

The mean GY values determined in the irrigation skipping treatments in different phenological periods were given in Table 3. The effect of irrigation skipping on GY was significant $(p<0.01)$. While the highest mean GY $(14021.3 \mathrm{~kg}$ $\mathrm{ha}^{-1}$ ) was obtained in S1 treatment where full irrigation water was applied in all phenological periods, and followed by S3 (13467.2 $\left.\mathrm{kg} \mathrm{ha}^{-1}\right)$ and S4 (13341.1 kg ha-1). The lowest mean yield was obtained in the S2 $\left(12761.5 \mathrm{~kg} \mathrm{ha}^{-1}\right)$ treatment. The yield decreases compared to the $\mathrm{S} 1$ treatment were $8.98 \%$ in $\mathrm{S} 2,3.95 \%$ in $\mathrm{S} 3$, and $4.85 \%$ in $\mathrm{S} 4$ treatment (Table 3). The irrigation skipping in the vegetative and generative phenological periods of corn caused a higher yield decrease compared to the pollination period. The results revealed that irrigation skipping should not be applied in the entire vegetative period of corn, however, if the water is limited, then an irrigation event can be skipped in the early vegetative period. The vegetative and flowering periods are the most sensitive to water deficits which cause a considerable yield loss (Ali and Shui, 2009). The results were in agreement with the findings of Rajasekar et al. (2020), who reported $11.8 \mathrm{t} \mathrm{ha}^{-1}$ under well-irrigated and $10.1 \mathrm{t} \mathrm{ha}^{-1}$ under skipping irrigation in the vegetative period conditions.

In a study conducted by Song et al. (2019), most of them neglect the influence of water stress during the seedling stage on the young corn growth and final yield. Water stress reduces the leaf area, canopy height, number of kernels per spike, and unit kernel weight during the seedling, silking, and grain-filling stages, respectively. A strong water stress during the vegetative growth stage could seriously inhibit the growth and leaf area of corn plants and decrease the yield (Salvador, 2015).

The highest chlorophyll content (44.50 SPAD) was obtained in the S1 treatment, while the lowest $\mathrm{CC}$ (39.10 SPAD) was recorded in the S4 treatment. The CC was the lowest in the generative development period (S4) (Table 3). Chlorophyll, the pigment of photosynthesis, is thought to suffer from water stress at a time when it has to produce nutrients. In a study by Maazou et al. (2016), chlorophyll values have been reported to reach the highest value under ideal climatic conditions and full irrigation. It has been reported that chlorophyll ratio decreases under low relative moisture and high-temperature conditions. Corn plants close their stomata, slow down photosynthesis and reduce gas exchange in chloroplasts thus, it has been stated that plants intake less $\mathrm{CO}_{2}$. 
Table 3. Grain yield and chlorophyll content determined in the irrigation skipping during different phenological periods of $\operatorname{corn}^{I}$

\begin{tabular}{|c|c|c|c|c|c|c|c|c|c|}
\hline \multirow{2}{*}{$\begin{array}{l}\text { Phenological } \\
\text { periods }\end{array}$} & \multicolumn{3}{|c|}{ GY $\left(\mathrm{kg} \mathrm{ha}^{-1}\right)$} & \multicolumn{3}{|c|}{ CC (spad) } & \multicolumn{3}{|c|}{ Irrigation $(\mathrm{mm})$} \\
\hline & 2017 & 2018 & Mean & 2017 & 2018 & Mean & 2017 & 2018 & Mean \\
\hline $\mathrm{S} 1$ & 12076.3 & $15966.3 \mathrm{a}$ & $14021.3 \mathrm{a}$ & $39.63 \mathrm{a}$ & $49.37 \mathrm{a}$ & $44.50 \mathrm{a}$ & 676.71 & 494.71 & 585.71 \\
\hline S2 & 10816.5 & $14706.5 \mathrm{~b}$ & $12761.5 \mathrm{c}$ & $39.13 \mathrm{a}$ & $48.87 \mathrm{a}$ & $44.00 \mathrm{a}$ & 601.65 & 419.65 & 510.65 \\
\hline S3 & 11522.2 & $15412.2 \mathrm{ab}$ & $13467.2 \mathrm{~b}$ & $37.79 a b$ & $47.53 \mathrm{a}$ & $42.66 \mathrm{a}$ & 580.80 & 398.80 & 489.80 \\
\hline S4 & 11396.1 & $15286.1 \mathrm{ab}$ & $13341.1 \mathrm{~b}$ & $34.23 \mathrm{~b}$ & $43.97 \mathrm{~b}$ & $39.10 \mathrm{~b}$ & 609.60 & 427.60 & 518.60 \\
\hline Mean $^{* *}$ & $11452.8 \mathrm{~b}$ & $15342.8 \mathrm{a}$ & 13397.8 & $37.69 \mathrm{~b}$ & $47.43 \mathrm{a}$ & 42.56 & & & \\
\hline CV (\%) & 18.72 & 3.54 & 12.00 & 8.46 & 2.93 & 6.48 & & & \\
\hline $\operatorname{LSD}_{(0.05)}$ & ns & $1086.66^{*}$ & $1990.04^{* *}$ & $6.37^{*}$ & $2.78^{* *}$ & $3.40^{* *}$ & & & \\
\hline Mean LSD & & $6185.93^{* *}$ & & & $2.39^{* *}$ & & & & \\
\hline
\end{tabular}

Table 4. Water use efficiency and crop water stress index and plant water consumption determined in the irrigation skipping during different phenological periods of corn $^{l}$

\begin{tabular}{|c|c|c|c|c|c|c|c|c|c|}
\hline \multirow{2}{*}{$\begin{array}{l}\text { Phenological } \\
\text { periods }\end{array}$} & \multicolumn{3}{|c|}{ WUE (mm) } & \multicolumn{3}{|c|}{ CWSI } & \multicolumn{3}{|c|}{ ETa $\left(\mathrm{mm} \mathrm{ha}^{-1}\right)$} \\
\hline & 2017 & 2018 & Mean & 2017 & 2018 & Mean & 2017 & 2018 & Mean \\
\hline $\mathrm{S} 1$ & 1.369 & $2.434 \mathrm{~b}$ & $1.902 \mathrm{~b}$ & $0.28 \mathrm{~b}$ & $0.14 \mathrm{c}$ & $0.21 \mathrm{bc}$ & 8824.56 & $6599.44 \mathrm{a}$ & 7712.00 \\
\hline $\mathrm{S} 2$ & 1.354 & $2.548 \mathrm{ab}$ & $1.951 \mathrm{ab}$ & $0.33 \mathrm{ab}$ & $0.19 \mathrm{~b}$ & $0.26 \mathrm{~b}$ & 7978.56 & $5753.44 \mathrm{~b}$ & 6866.00 \\
\hline $\mathrm{S} 3$ & 1.475 & $2.753 \mathrm{a}$ & $2.114 \mathrm{a}$ & $0.25 \mathrm{~b}$ & $0.11 \mathrm{c}$ & $0.18 \mathrm{c}$ & 7864.56 & $5639.44 \mathrm{~b}$ & 6752.00 \\
\hline S4 & 1.416 & $2.623 \mathrm{ab}$ & $2.019 \mathrm{ab}$ & $0.40 \mathrm{a}$ & $0.26 \mathrm{a}$ & $0.33 \mathrm{a}$ & 8056.56 & $5831.44 \mathrm{~b}$ & 6944.00 \\
\hline Mean $^{* *}$ & $1.404 \mathrm{~b}$ & $2.590 \mathrm{a}$ & 1.997 & $0.32 \mathrm{a}$ & $0.18 \mathrm{~b}$ & 0.25 & $8181.06 \mathrm{a}$ & $5955.94 \mathrm{~b}$ & 7068.50 \\
\hline CV $(\%)$ & 8.66 & 5.55 & 6.66 & 18.31 & 9.76 & 19.42 & 15.22 & 4.86 & 13.35 \\
\hline $\operatorname{LSD}_{(0.05)}$ & $\mathrm{ns}$ & $0.29^{*}$ & $0.19 *$ & $0.12^{*}$ & $0.03^{* *}$ & $0.06^{* *}$ & ns & $578.11^{*}$ & $1166.06^{\mathrm{ns}}$ \\
\hline Mean LSD & & $0.16^{* *}$ & & & $0.05^{* *}$ & & & $824.52^{* *}$ & \\
\hline
\end{tabular}

1: Similar letter in the same column are not significantly different from each other, WUE: Water use efficiency, CWSI: Crop water stress index, ETa: Plant water consumption, CV: Coefficient of variation, *: Significant at 0.05 level of probability, **: Significant at 0.01 level of probability, S1: Full irrigation treatments (Control), S2: Irrigation skipping in the vegetative growth period, S3: Irrigation skipping in pollination period, S4: Irrigation skipping in the generative development period, ns: Not-significant

The highest plant CWSI (0.33) (excluding the full irrigation, S1 treatment) was obtained in S4, while the lowest CWSI (0.18) was obtained in S3 treatment where the chlorophyll content was higher (Table 4). The CWSI was increased in the first year of the study when unfavorable climatic conditions prevailed under skipping irrigation treatments.

Previous studies indicated that the CWSI value varies depending on the type and variety of plant species, environmental and climatic conditions of the growth environment (Alderfasi and Nielsen, 2001; Testi et al., 2008; Song et al., 2019).

The highest WUE (2.114) value was obtained in S3 phenological period treatment, while the lowest WUE value (1.902) was determined in S1 phenological period treatment. The increase in the amount of irrigation water caused a decrease in WUE values (Table 4). Similar results were also reported by Mahmoud and Ahmed (2016) and Song et al. (2019) who reported that WUE increased with the decrease in the amount of irrigation water. In accordance with the study, Sah et al. (2020) found that under limited irrigated conditions WUE was higher than that of full irrigation but in terms of profitability, full irrigation was more desirable.
The results of the correlation test to determine the relationships between plant water consumption (ETa), yield, CWSI, WUE, and CC, are given in Table 5. The ETa had significant $(p<0.01)$ correlations with physiological parameters except for GY. Positive and significant relationships were found between $\mathrm{GY}$ and $\mathrm{CC}(\mathrm{r}=0.784, \mathrm{p}<0.01)$, and WUE $(r=0.740, p<0.01)$. Negative and significant relationships were found between GY and CWSI $(\mathrm{r}=-0.521, \mathrm{p}<0.01)($ Table 5).

A significant positive correlation between the ETa values and CWSI $(r=0.608, p<0.01)$ indicates that the CWSI value increased as the ETa increased but this did not increase the grain yield. A significant negative correlation $(r=-0.473, p<0.05)$ was obtained between the ETa values and CC (Table 5). Under stress conditions, although plant water consumption increased, this increase was not sufficient and chlorophyll contents decreased. Grain yields have also decreased depending on this situation. Consistent with our study, it was reported that positive relationships were found between corn grain yield and chlorophyll content and water use efficiency in a study (Eissa and Nadia, 2019). Bhagat et al. (2019) opined that the water stress 
Table 5. Correlation coefficients and significance levels of yield components and grain yield and physiological parameters

\begin{tabular}{|c|c|c|c|c|c|c|c|c|}
\hline Traits & Traits & $\begin{array}{l}\text { Correlation } \\
\text { coefficients } \\
\text { (r) }\end{array}$ & Count & $\begin{array}{c}\text { The lowest } \\
\text { coefficients } \\
(95 \%)\end{array}$ & $\begin{array}{l}\text { The highest } \\
\text { coefficients } \\
(95 \%)\end{array}$ & $\begin{array}{c}\text { Significance } \\
\text { levels }\end{array}$ & Correlation levels & \\
\hline WUE & ETa & -0.785 & 24 & -0.902 & -0.558 & $<.0001^{* *}$ & & \\
\hline CWSI & ETa & 0.608 & 24 & 0.272 & 0.812 & $0.0016^{* *}$ & & \\
\hline CWSI & WUE & -0.701 & 24 & -0.860 & -0.414 & $0.0001^{* *}$ & & \\
\hline $\mathrm{CC}$ & ETa & -0.473 & 24 & -0.736 & -0.087 & $0.0193^{*}$ & & \\
\hline $\mathrm{CC}$ & WUE & 0.777 & 24 & 0.545 & 0.899 & $<.0001^{* *}$ & & \\
\hline $\mathrm{CC}$ & CWSI & -0.800 & 24 & -0.910 & -0.587 & $<.0001^{* *}$ & & \\
\hline GY & $\mathrm{ETa}$ & -0.192 & 24 & -0.553 & 0.228 & $0.3670^{\mathrm{ns}}$ & & \\
\hline GY & WUE & 0.740 & 24 & 0.480 & 0.880 & $<.0001^{* *}$ & & \\
\hline GY & CWSI & -0.521 & 24 & -0.764 & -0.149 & $0.0089^{* *}$ & & \\
\hline GY & $\mathrm{CC}$ & 0.784 & 24 & 0.558 & 0.902 & $<.0001^{* *}$ & & \\
\hline
\end{tabular}

ns: Not significant, *: Significant at 0.05 level of probability, **: Significant at 0.01 level of probability

reduced the photosynthetic rate with increased levels of stress in corn.

\section{Conclusions}

The results revealed that irrigation skipping in phenological periods of corn had a significant impact on yield and some physiological parameters. Statistically significant differences were obtained between years in all parameters. Compared to the second year of the study, the environmental stress conditions experienced in the first year of the study negatively affected all parameters, especially the grain yield. Correlation coefficients showed statistically significant relationships $(\mathrm{p} \leq 0.01)$ between the parameters investigated. Despite the relatively lower decrease in yield, the irrigation skipping in the vegetative period caused a higher grain yield decrease in both years. Excluding the yield in the control treatment $\left(14021.3 \mathrm{~kg} \mathrm{ha}^{-1}\right)$, the highest yield (13467.2 $\mathrm{kg} \mathrm{ha}^{-1}$ ) was obtained in irrigation skipping at pollination period (S3), while the lowest yield $\left(12761.5 \mathrm{~kg} \mathrm{ha}^{-1}\right)$ was recorded in the vegetative period irrigation skipping treatment (S2). The results revealed that irrigation skipping should not be applied during the entire vegetative period of corn, but if the irrigation skipping is imperative, then it can be applied for a short time in the early vegetative period. The irrigation skipping during the entire vegetative period of corn causes insufficient growth, shorter plant height, and a low number of leaves and the plants could not form large cobs. Therefore, irrigation skipping should not be applied during the entire vegetative phenological period (lasting until flowering) for economical and profitable corn production.

\section{References}

Alderfasi, A.A., Nielsen, D.C., 2001. Use of crop water stress index for monitoring water status and scheduling irrigation in wheat. Agricultural Water Management, 47(2): 69-75.

Ali, M.D., Shui, L.T., 2009. Potential evapotranspiration model for Muda Irrigation Project, Malaysia. Water Resources Management, 23(1): 57-69.

Anonymous, 2017. Trials Technical Instruction for Measuring Agricultural Values of Maize (Zea mays L.). Ministry of Agriculture and Forestry, General Directorate of Plant Production, Seed Registration and Certification Directorate, Ankara, Turkey. (In Turkish).

Anonymous, 2018a. Area and Production Quantities of Cereals and Other Crop Products. Turkish Statistical Institute, (http://tuikapp.tuik.gov.tr), (Date of access: 11.11.2018). (In Turkish).

Anonymous, 2018b. Meteorological Data of Şanliurfa Province. General Directorate of State Meteorology Affairs, Adana, Turkey. (In Turkish).

Anonymous, 2019. World Agricultural Production. United States Department of Agriculture (USDA) Circular Series, WAP 12-19, (Date of access: 12.12.2019).

Bhagat, A.P., Bhale, V.M., Saoji, B.V., Kubde, K.J., Kharche, V.K., Kadu, P.R., 2019. Reciprocating preliminary effect on fodder maize as influenced by irrigation regimes and fertilizer levels grown in summer season. Annals of Botany, 103(4): 581-597.

Bu, L., Zhang, R., Chang, Y., Xue, J., Han, M., 2010. Response of photosynthetic characteristics to water stress of maize leaf in seeding. International Journal of Acta Ecologica Sinica, 30: 1184-1191.

Cakir, R., 2004. The effect of water stress at different development stages on vegetative and reproductive growth of corn. Field Crop Research, 89(5): 1-16.

Chakraborty, M., Ghosh, J., Sah, R.P., 2012. Combining ability studies for yield and other traits in maize (Zea mays L.). Journal of Plant Archives, 12(1): 235-238.

Denmead, O.T., Shaw, R.H., 1960. The effects of soil moisture stress at different stages of growth on the development and yield of corn. Journal of Agronomy, 52(2): 272-274. 
Der, G., Everitt, B.S., 2002. A Handbook of Statistical Analyses Using SAS. Second Edition, CRC Press LLC, 2000 N.W. Corporate Blvd., Boca Raton, Florida, USA.

Eissa, M.A., Nadia, M.K.R., 2019. Effect of nitrogen rates on drip irrigated maize grown under deficit irrigation. Journal of Plant Nutrition, 42(2): 127-136.

Idso, S.B., Jackson, R.D., Pinter, P.J., 1982. Canopy temperature as a crop water stress indicator. Water Resources Research, 17(4): 1133-1138.

Igbadun, H.E., Tarimo, A.K., Salim, B.A., Mahoo, H.F., 2007. Evaluation of selected crop water production functions for an irrigated maize crop. Agriculture Water Managament, 94(3): 1-10.

Jaleel, C.A., Manivannan, P., Wahid, A., Farooq, M., AL Juburi, H.J., Somasundar, R., Pannerersel, R., 2009. Drought stress in plants: A review on morphological characteristics and pigments composition. Journal of Agriculture Biology, 11(4): 100-105.

Jasim, A.H., Sura, H.R., Hanaa, H.M., 2020. Effect of skip irrigation and nano potassium treatments on maize yield. Journal of Eco-Environmental Consultants, 26(3): 10-15.

Kanemasu, E.T., Asrar, G., Yoshida, M., 1985. Remote sensing techniques for assessing water deficits and modeling crop response. Journal of Hortscience, 20(6): 1043-1046.

Maazou, A.R.S., Tu, J.L., Qiu, J., Liu, Z.Z., 2016. Breeding for drought tolerance in maize (Zea mays L.). American Journal of Plant Sciences, 7(6): 1858-1870.

Mahmoud, A.M., Ahmed, T.A., 2016. Water use efficiency of sunflower genotypes under drip irrigation. African Journal of Agricultural Research, 11(2): 925-929.

Pandit, M., 2016. Genetic diversity assay of maize (Zea mays L.) inbreds based on morphometric traits and SSR markers. African Journal of Agricultural Research, 11(24): 2118-2128.

Pandit, M., 2017. Identification of maize genotypes for moisture stress tolerance. International Journal of Basic and Applied Biology, 4(2): 74-81.

Pandit, M., 2018. Gene action and combining ability for dual purpose traits in maize (Zea mays L.) under water deficit stress prevailing in eastern India. Range Managament \& Agroforestry, 39(1): 29-37.
Rajasekar, M., Abul-Hassan, S., Karthik, A., 2020. Effect of moisture deficit conditions on the performance of maize (Zea mays L.). International Journal of Chemical Studies, 8(2): 2603-2609.

Sah, R.P., Chakraborty, M., Prasad, K., Pandit, M., Tudu, V.K., Chakravarty, M.K., Narayan, S.C., Rana, M., Moharana, D., 2020. Impact of water deficit stress in maize: Phenology and yield components. Nature Research, 10: 2944.

Salvador, R.J., 2015. Proposed standard system of nomenclature for maize grain filling events and concepts. Journal of Maydica, 40(4): 141-146.

Sarikurt, B., Bengisu, G., 2020. Determination research on the determining of yield and some agricultural characters and the relationship among the characters on maize cultivars grown as second crop under irrigated conditions of Diyarbakir plain. European Journal of Science and Technology, 3(18): 243-247. (In Turkish).

Song, L., Jin, J., He, J., 2019. Effects of severe water stress on maize growth processes in the field. International Journal of Sustainability, 11(2): 1-18.

Steele, D.D., Stegman, E.C., Knighton, R.E., 2000. Irrigation management for corn in the northern Great Plains, USA. Journal of Irrigation Science, 19(2): 107-114.

Tariq, J., Usman, K., 2009. Regulated deficit irrigation scheduling of maize crop. Journal of Sarhad Agriculture, 25(4): 441-450.

Testi, L., Goldhamer, D.A., Iniesta, F., Salinas, M., 2008. Crop water stress index is a sensitive water stress indicator in pistachio trees. Journal of Irrigation Science, 26(2): 395-405.

Xiao, Y.N., Li, X.H., George, M.L., Li, M.S., Zhang, S.H., Zheng, Y.L., 2005. Quantitative trail locus analysis of drought tolerance and yield in maize in China. Journal of Plant Molecular Biology, 23(3): 155-165.

Yazar, A., 2009. Irrigation and Drainage Lecture Notes. Çukurova University Agriculture Faculty of Agricultural Structures and Irrigation, Adana, Turket. (In Turkish).

Zeleke, K.T., Wade, L.J., 2012. Evapotranspiration estimation using soil water balance. Weather and Crop Data, Rijeka, Croatia, pp. 41-58. 